\title{
Active carbons from waste biochars
}

\section{Structural and thermal properties}

\author{
Jadwiga Skubiszewska-Zięba ${ }^{1} \cdot$ Barbara Charmas $^{1} \cdot$ Michał Kołtowski $^{1}$ \\ Patryk Oleszczuk ${ }^{1}$
}

Received: 13 November 2016/Accepted: 3 February 2017/Published online: 21 February 2017

(C) The Author(s) 2017. This article is published with open access at Springerlink.com

\begin{abstract}
Studies of preparation of active carbons of good structural and adsorption properties based on commercial biochars, which become wastes after removal of precious volatile components from natural raw materials of different origin, i.e., from wheat straw, Miscanthus grass, walnut shells, and energetic willow were carried out. There was applied the physical activation under atmospheric pressure in the fluidal reactor using $\mathrm{CO}_{2}$ or overheated steam and in the closed system in the high pressure microwave reactor under hydrothermal conditions. The obtained active carbons were investigated by means of adsorption $\left(\mathrm{N}_{2}\right)$, thermal (TG, DTG, DTA), spectral (Raman spectra) as well as electron microscopy methods. The adsorbents obtained as a result of modification were characterized by a welldeveloped porous structure and greater thermal resistance compared to the initial biochars.
\end{abstract}

Keywords Wastes - Biochars - Modification - Active carbons · Porous structure Thermal resistance

\section{Introduction}

Lately, due to increasing degradation of soil, the search for the ways of management of organic biodegradable wastes has been more and more intensive in soil quality improvement processes. It is connected with production of new materials to limit the use of chemical fertilizers and plant protection agents, reduction of greenhouse gases

Jadwiga Skubiszewska-Zięba

jskubisz@poczta.umcs.lublin.pl

1 Faculty of Chemistry, Maria Curie-Skłodowska University, Maria Curie Skłodowska Sq. 3, 20-031 Lublin, Poland emission as well as carbon sequestration in soil. Biochar can be a solution to these problems.

Making use of biochars in agriculture is not a new problem. It is assumed that they can be used, among others, for remediation of contaminated soils, sequestration of carbon in soil, improvement of composting conditions, improvement of soil properties, and removal of impurities from soils as well as underground and surface waters [1-11].

The materials used for production of biochars are raw materials of natural origin including energetic plants, forestry and agricultural wastes, sludges and organic fraction of municipal wastes, agriculture and food processing wastes, and many others $[12,13]$. Choice of substrates for biomass production depends on their physicochemical properties and predicted applications. Biochar is obtained in the pyrolysis process which consists in the thermal conversion of plant biomass or organic waste under oxygen-free conditions. During treatment at about 350-700 ${ }^{\circ} \mathrm{C}$, besides biochar, some highly energetic liquid and gas products (oil being a mixture of liquid hydrocarbons and synthetic gas being a mixture of gas hydrocarbons) are formed. Proportions of the pyrolysis products depend on the kind of initial material and process conditions: range and rate of changes of temperature, time, pressure, and atmosphere [14-23]. The choice of pyrolysis parameters affects productivity and quality of the obtained biochar.

Biochar obtained at a temperature lower than $400{ }^{\circ} \mathrm{C}$ is characterized by very low-specific surface area and poorly developed pores structure. Therefore, it does not exhibit desired adsorption properties. This refers to the biochars which are the residue from the processes of obtaining of gas and liquid products from plant materials. One of the methods used for modification of carbon material porous 
structure is activation in the oxidizing atmosphere $\left(\mathrm{H}_{2} \mathrm{O}\right.$, $\mathrm{CO}_{2}, \mathrm{H}_{2} \mathrm{O}_{2}, \mathrm{O}_{2}+\mathrm{N}_{2}$ ). During this process, partial carbon gasification takes place using the oxidizing agents [12, 24-28]. Then the finest, unstructurized particles of carbon matter are oxidized and thus the pores structure is developed. In the modification of biocarbon porous structure, the results of using of microwave energy are also noteworthy. There are some reports [29-32] that in such conditions carbon can reach the temperature up to $900{ }^{\circ} \mathrm{C}$ or even higher. High temperature and oxidizing properties of overheated water vapor create perfect conditions for activation (gasification) of carbon phase. The aim of this paper was to work out some methods for development of porous structure of commercial biochars, which become wastes after removal of precious volatile components and to determine the properties of the obtained active carbons.

\section{Experimental}

\section{Preparation of initial materials}

For the investigations, there were used commercial biochars prepared from raw natural materials: wheat straw (WS), Miscanthus grass (MG), walnut shells (WN), and energetic willow (EW). Biochar from wheat straw (WS-ini) was powdery and also consisted of grains of various size and shape. In order to obtain a more homogeneous fraction, the material was passed through the sieves of different size of meshes. The middle fraction $0.63 \mathrm{~mm}<d<0.8 \mathrm{~mm}$ was used in the studies. In order to obtain a representative sample of biocarbon from the walnut shells (WN-ini), the material was disintegrated in the mortar and passed through the sieves of different mesh sizes, and the fraction $0.63 \mathrm{~mm}<d<0.8 \mathrm{~mm}$ was used in the studies.

In the case of biocarbons from Miscanthus grass (MGini) and energetic willow (EW-ini), the grains of both biocarbons had a needle shape, difficult to be separated on sieves, so they were studied in the original form without disintegration and sifting.

\section{Activation}

\section{Activation in dynamic conditions}

Biochar samples were activated in the quartz fluidal reactor at $800{ }^{\circ} \mathrm{C}$ using carbon dioxide or overheated water vapor as oxidation agents. The weighed samples were ca. $7 \mathrm{~g}$. In the case of activation with $\mathrm{CO}_{2}$, this gas flow during all stages of the process $\left(100 \mathrm{~mL} \mathrm{~min}{ }^{-1}\right)$, i.e., during temperature increase from 20 to $800{ }^{\circ} \mathrm{C}$ with the rate $10{ }^{\circ} \mathrm{C} \mathrm{min}{ }^{-1}$, isothermal heating at $800{ }^{\circ} \mathrm{C}$ for $1 \mathrm{~h}$, and cooling to room temperature. The activated carbons obtained in this procedure were designated as WS- $\mathrm{CO}_{2}$, $\mathrm{WN}-\mathrm{CO}_{2}, \mathrm{MG}-\mathrm{CO}_{2}$, and EW-CO ${ }_{2}$, respectively. During activation by means of water vapor, the following stages can be distinguished: temperature increase from 20 to $800{ }^{\circ} \mathrm{C}$ with the rate $10{ }^{\circ} \mathrm{C} \mathrm{min}^{-1}$ in the $\mathrm{N}_{2}$ atmosphere (flow $100 \mathrm{~mL} \mathrm{~min}{ }^{-1}$ ), isothermal heating at $800{ }^{\circ} \mathrm{C}$ in the water vapor atmosphere for $1 \mathrm{~h}$. Here, the fluidal reactor was supplied with water with the rate $0.6 \mathrm{~mL} \mathrm{~min}^{-1}$ through the vapor saturator heated up to $200{ }^{\circ} \mathrm{C}$. At the end, it was cooled to room temperature in the $\mathrm{N}_{2}$ atmosphere with the flow rate $100 \mathrm{~mL} \mathrm{~min}{ }^{-1}$. The activated carbons obtained in this procedure were designated as WS$\mathrm{H}_{2} \mathrm{O}, \mathrm{WN}-\mathrm{H}_{2} \mathrm{O}, \mathrm{MG}-\mathrm{H}_{2} \mathrm{O}$, and $\mathrm{EW}-\mathrm{H}_{2} \mathrm{O}$, respectively.

\section{Hydrothermal activation using microwave energy}

All initial biochars (WS-ini, WN-ini, MG-ini, EW-ini) were modified in the microwave reactor $(300 \mathrm{~W}$, NANO 2000, Plazmatronika, Poland) in the water vapor atmosphere. A $1.5 \mathrm{~g}$ of biochar was weighed from each sample. A dry sample was placed in a quartz cell which was put into a Teflon thimble of the microwave reactor. Twenty milliliters of distilled water was poured on the bottom of thimble. The tightly closed system was exposed to microwave energy. The modification conditions: time- $-30 \mathrm{~min}$; pressure $-45 \mathrm{~atm}$; and temperature $-200{ }^{\circ} \mathrm{C}$. The samples obtained after activation in the microwave reactor were named: WS-micr, WN-micr, MG-micr, EW-micr.

\section{Investigation methods}

\section{Low-temperature adsorption/desorption isotherms} of nitrogen

In order to study the porous structure of the obtained carbon adsorbents, there were determined the low-temperature adsorption/desorption nitrogen isotherms at $77.4 \mathrm{~K}$ using the apparatus ASAP 2405 (Micromeritics, Norcross GA, USA). Before measurements, the samples were degassed at $200{ }^{\circ} \mathrm{C}$ under vacuum $\left(5 \times 10^{-3}\right.$ Torr $)$ to reach a constant pressure in burette. From the obtained data, the specific surface area $\left(S_{\mathrm{BET}}\right)$ was calculated according to the standard BET method [33]. The total sorption pore volume $\left(V_{\mathrm{p}}\right)$ was evaluated from the nitrogen adsorption at $p / p_{0} \approx 1$ ( $p$ and $p_{0}$ denote the equilibrium and saturation pressures of nitrogen at $77.4 \mathrm{~K}$, respectively) [33] and average pores radius $\left(R_{\mathrm{av}}=2 V_{\mathrm{p}} / S_{\mathrm{BET}}\right)$ assuming their cylindrical shape was determined. Specific surface area of micropores $S_{\text {mic }}$ and their volume $V_{\text {mic }}$ were determined using $t$-plot method [33]. Using the desorption branch data, the functions of pore volume distribution $\mathrm{d} V / \mathrm{d} R=f(R)$ and cumulative area of pores $S_{\mathrm{BJH}}$ were determined using the BJH method, where cylindrical pore shapes are considered [34]. 


\section{Thermogravimetric analysis}

Thermal properties and carbon matter contents in the analyzed biochars were studied using Derivatograph C (Paulik, Paulik and Erdey, MOM, Hungary). The samples were placed in ceramic crucibles using aluminum oxide as the reference substance. The weighed mass was about $40 \mathrm{mg}$. The measurements were taken in the temperature range $20-1200{ }^{\circ} \mathrm{C}$ with the temperature increase $10{ }^{\circ} \mathrm{C} \mathrm{min}{ }^{-1}$ in the air atmosphere. The TG, DTG, and DTA curves were registered.

\section{Raman spectra}

In order to obtain information about carbon matter structure in the studied adsorbents, there were made Raman spectra using Microscope DMLM Leica Research Grade, inVia Reflex (Renishaw, UK). Excitation was achieved using laser $514 \mathrm{~nm}$. The resolution was $1 \mathrm{~cm}^{-1}$ and accumulation of 4 spectra.

\section{Electron scanning microscopy}

Morphology of biochars surface was studied using the SEM technique on the high-resolution electron-ionic scanning microscope DualBeam Quanta 3D FEG (FEI, USA) in the condition of high vacuum (accelerating voltage $5 \mathrm{kV}$, magnification from $\times 200$ to $\times 100,000)$.

\section{Results and discussion}

\section{Structural analysis}

Figure 1 presents the nitrogen adsorption/desorption isotherms and the differential functions of pore volume distribution in relation to their average radii for all studied samples. According to the IUPAC recommendation [35], all isotherms presented in this figure can be classified as type IV. As follows from the analysis of their shape, the initial sample of biochar prepared from wheat straw (WSini, Fig. 1a) is characterized by poorly developed porosity. Insignificant adsorption is observed in the whole range of low relative pressures. However, the isotherms of the samples modified in the fluidal (WS- $\mathrm{H}_{2} \mathrm{O}, \mathrm{WS}-\mathrm{CO}_{2}$ ) and microwave (WS-micro) reactors are characterized by large adsorption at low $p / p_{0}$ which indicates microporosity (particularly in the case of the sample $\mathrm{WS}-\mathrm{CO}_{2}$ ) and also by distinct hysteresis loops evidencing development of mesopores structure. According to the IUPAC classification [35], these loops belong to the $\mathrm{H} 3$ type indicating the occurrence of pores of slit-like shape and capillary of nonparallel walls, which is typical of carbon adsorbents.
The above observations are confirmed by the course of pores volume distribution curves in relation to their average radii are presented in Fig. 1a (right picture). As can be seen the modification in both fluidal and microwave reactors causes intensive development of micro- and mesoporous structures. However, for the adsorbent activated with water vapor (WS- $\mathrm{H}_{2} \mathrm{O}$ ), the peak maximum in the range of transition pores is shifted toward wider radii (over $2 \mathrm{~nm}$ ) compared to the corresponding peaks for the other adsorbents (less than $2 \mathrm{~nm}$ ).

A different course of the nitrogen adsorption/desorption isotherms and function of pores volume distribution in relation to their average radii is presented in Fig. $1 \mathrm{~b}$ for the series of samples obtained from the initial biochar from Miscanthus grass (MG-ini) modified in the microwave (MG-micr) and fluidal $\left(\mathrm{MG}-\mathrm{CO}_{2}, \mathrm{MG}-\mathrm{H}_{2} \mathrm{O}\right)$ reactors. The isotherm for the sample MG-ini is not presented due to very low adsorption.

As follows from the analysis of curves courses in Fig. 1b, similar to the case of biochar WS, all activation forms lead to development of porous structure, both micro- and mesoporosity. Modification in the fluidal reactor using overheated water vapor $\left(\mathrm{MG}-\mathrm{H}_{2} \mathrm{O}\right)$ proved to be the most effective. The isotherm for this sample takes the highest position in relation to the adsorption/desorption axis (Fig. 1b, left picture), but intensive peaks for micropores $\left(R_{\mathrm{p}}\right.$ about $\left.1 \mathrm{~nm}\right)$ and mesopores $\left(R_{\mathrm{p}}\right.$ over $\left.2 \mathrm{~nm}\right)$ are observed on the pores volume distribution function (Fig. 1b, right picture).

Figure 1c, d present nitrogen adsorption/desorption isotherms and differential functions of pore volume distribution for the series of biochars prepared from walnut shells (WN) and energetic willow (EW) modified in different ways. There is observed similar tendency taking into account the courses of isotherm curves (Fig. 1c, d, left pictures) as well as pores distribution (Fig. 1c, d, right pictures).

Table 1 shows the structural characteristics of initial biochars and those modified under different conditions. The analysis of the data confirms the conclusions drawn from the shape of adsorption/desorption isotherms as well as pores distribution function.

In the case of the series of WS samples, the activation using $\mathrm{CO}_{2}$ proved to be the most effective procedure. The specific surface area $S_{\mathrm{BET}}$ of the biochar $\mathrm{WS}-\mathrm{CO}_{2}$ is $304.7 \mathrm{~m}^{2} \mathrm{~g}^{-1}$ and is 11.6 times larger than $S_{\mathrm{BET}}$ of the initial sample WS-ini. The significant increase was observed in the case of other structural parameters such as $S_{\text {mic }}=221.8 \mathrm{~m}^{2} \mathrm{~g}^{-1}$-about 20-fold increase; $V_{\mathrm{p}}=$ $0.154 \mathrm{~cm}^{3} \mathrm{~g}^{-1}$-about sixfold increase; $V_{\text {mic }}=0.0982$ $\mathrm{cm}^{3} \mathrm{~g}^{-1}$-about 21-fold increase compared to the initial parameter of the sample WS-ini.

Slightly smaller changes in the porous structure were observed for the sample modified in the fluidal reactor in 
Fig. 1 Low-temperature nitrogen adsorption/desorption isotherms (left pictures) and differential pore volume distribution functions (right pictures) for series of biochars differently activated: wheat straw WS (a); Miscanthus grass $M G(\mathbf{b})$; walnut shells $W N(\mathbf{c})$; and energetic willow $E W(\mathbf{d})$
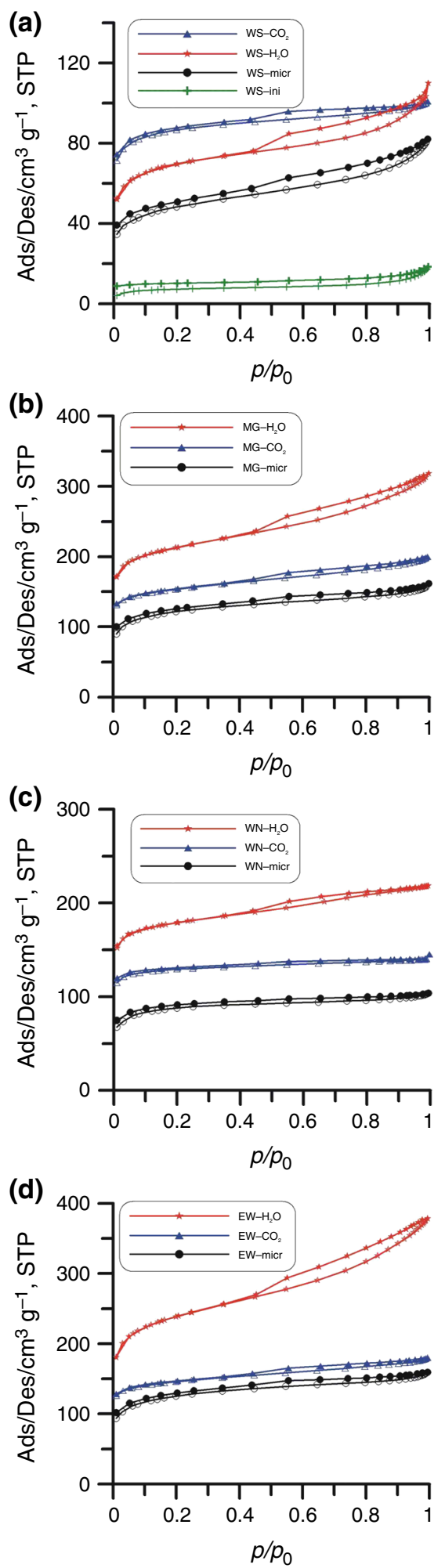
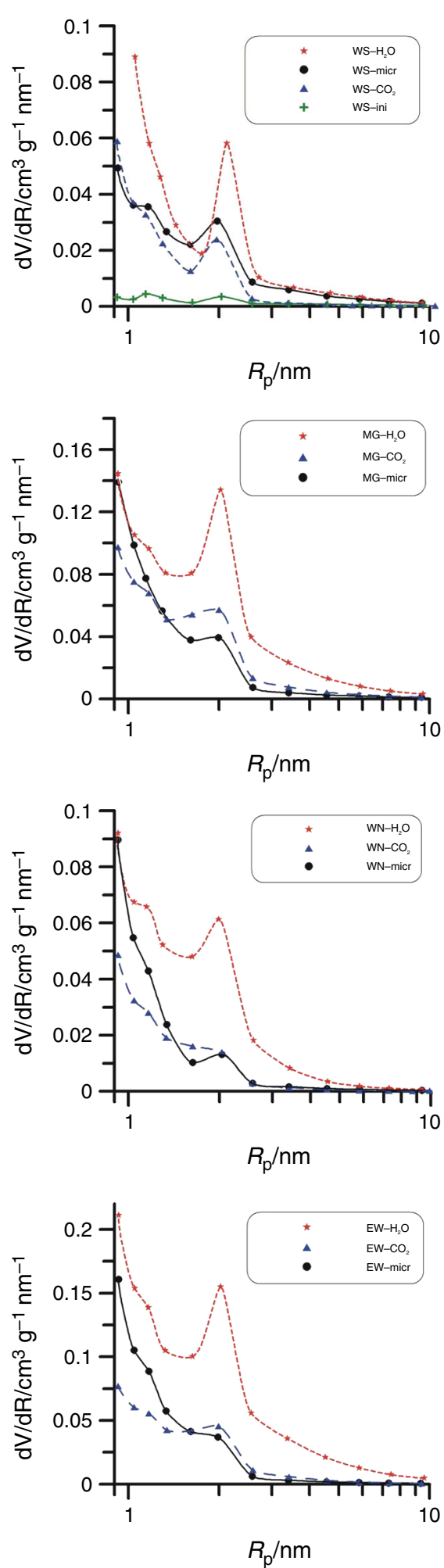

the overheated water vapor atmosphere. The specific surface area of this biochar was $246.2 \mathrm{~m}^{2} \mathrm{~g}^{-1}$ and is about nine times larger than $S_{\mathrm{BET}}$ of the initial material WS-ini. The increase was also found in the other parameters, i.e., $S_{\text {mic }}=140.4 \mathrm{~m}^{2} \mathrm{~g}^{-1}$ —about 13-fold increase;
$V_{\mathrm{p}}=0.1587 \mathrm{~cm}^{3} \mathrm{~g}^{-1}$-about sixfold increase; $V_{\text {mic }}=0.0622 \mathrm{~cm}^{3} \mathrm{~g}^{-1}$-about 13-fold increase compared to the parameters of the initial biochar WS-ini.

The smallest changes of porous structure parameters were observed for the biochar obtained by the 
Table 1 Parameters of porous structure for initial biochars and active carbons prepared on their basis using different activation procedures

\begin{tabular}{|c|c|c|c|c|c|c|c|c|}
\hline Sample & $S_{\mathrm{BET}} / \mathrm{m}^{2} \mathrm{~g}^{-1}$ & $S_{\text {mic }} / \mathrm{m}^{2} \mathrm{~g}^{-1}$ & $S_{\mathrm{BJH}} / \mathrm{m}^{2} \mathrm{~g}^{-1}$ & $S_{\mathrm{mic}} / S_{\mathrm{BET}} / \%$ & $V_{\mathrm{p}} / \mathrm{cm}^{3} \mathrm{~g}^{-1}$ & $V_{\mathrm{mic}} / \mathrm{cm}^{3} \mathrm{~g}^{-1}$ & $V_{\mathrm{mic}} / V_{\mathrm{p}} / \%$ & $R_{\text {ave }} / \mathrm{nm}$ \\
\hline WS-ini & 26.3 & 10.8 & 8.5 & 41.1 & 0.0256 & 0.0046 & 18 & 1.95 \\
\hline $\mathrm{WS}-\mathrm{CO}_{2}$ & 304.7 & 221.8 & 39.8 & 72.8 & 0.1540 & 0.0982 & 64 & 0.80 \\
\hline $\mathrm{WS}-\mathrm{H}_{2} \mathrm{O}$ & 246.2 & 140.4 & 153.2 & 57.0 & 0.1587 & 0.0622 & 39 & 1.02 \\
\hline WS-micr & 170.8 & 74.1 & 77.9 & 43.0 & 0.1230 & 0.0329 & 27 & 1.43 \\
\hline MG-ini & 0.8 & 0.2 & 0.14 & 31.4 & 0.0010 & 0.0001 & 10 & 2.75 \\
\hline $\mathrm{MG}-\mathrm{CO}_{2}$ & 538.5 & 381.0 & 145.9 & 70.8 & 0.3047 & 0.1691 & 55 & 0.90 \\
\hline $\mathrm{MG}-\mathrm{H}_{2} \mathrm{O}$ & 748.7 & 489.7 & 264.2 & 65.4 & 0.4812 & 0.2170 & 45 & 1.02 \\
\hline MG-micr & 429.6 & 253.1 & 138.8 & 58.9 & 0.2411 & 0.1114 & 46 & 0.89 \\
\hline WN-ini & 3.1 & 2.3 & 0.001 & 74.5 & 0.0009 & 0.0087 & 1 & 0.60 \\
\hline $\mathrm{WN}-\mathrm{CO}_{2}$ & 453.1 & 380.4 & 50.0 & 84.0 & 0.2166 & 0.1688 & 77 & 0.76 \\
\hline $\mathrm{WN}-\mathrm{H}_{2} \mathrm{O}$ & 626.8 & 472.4 & 142.4 & 75.4 & 0.3361 & 0.2094 & 62 & 0.85 \\
\hline WN-micr & 310.8 & 197.6 & 68.4 & 63.6 & 0.1583 & 0.0873 & 55 & 0.81 \\
\hline EW-ini & 11.4 & 4.5 & 0.001 & 39.6 & 0.0061 & 0.0016 & 26 & 1.08 \\
\hline $\mathrm{EW}-\mathrm{CO}_{2}$ & 512.0 & 379.9 & 116.6 & 74.2 & 0.2758 & 0.1687 & 61 & 0.85 \\
\hline $\mathrm{EW}-\mathrm{H}_{2} \mathrm{O}$ & 840.6 & 509.3 & 353.6 & 60.6 & 0.5765 & 0.2245 & 39 & 1.09 \\
\hline EW-micr & 443.2 & 258.6 & 147.9 & 58.3 & 0.2424 & 0.1138 & 47 & 0.87 \\
\hline
\end{tabular}

$S_{\mathrm{BET}}$ specific surface area, $S_{\text {mic }}$ specific surface of micropores, $S_{\mathrm{BJH}}$ specific surface area determined by BJH method, $V_{\mathrm{p}}$ total volume of sorptive pores, $V_{\text {mic }}$ volume of micropores, $R_{\text {ave }}$ average pore radius

hydrothermal modification in the microwave reactor (WSmicro). The specific surface area of this sample was $170.8 \mathrm{~m}^{2} \mathrm{~g}^{-1}$ which means the sevenfold increase compared to the initial material surface. The micropores surface is $S_{\text {mic }}=74.1 \mathrm{~m}^{2} \mathrm{~g}^{-1}$ but $V_{\mathrm{p}}=0.123 \mathrm{~cm}^{3} \mathrm{~g}^{-1}$ and $V_{\text {mic }}=0.0329 \mathrm{~cm}^{3} \mathrm{~g}^{-1}$. This means sevenfold increase in $S_{\text {mic }}$ and $V_{\text {mic }}$ and about the fivefold increase in $V_{\mathrm{p}}$ compared to corresponding parameters of the biochar WS-ini.

As follows from the data in Table 1, the initial biochar MG-ini is practically non-porous $\left(S_{\mathrm{BET}}=0.8 \mathrm{~m}^{2} \mathrm{~g}^{-1}\right)$. However, due to modification with oxidizing agents, the obtained materials had a largely developed surface. Activation with water vapor in the fluidal reactor $\left(\mathrm{MG}-\mathrm{H}_{2} \mathrm{O}\right.$, $S_{\mathrm{BET}}=748.7 \mathrm{~m}^{2} \mathrm{~g}^{-1}, V_{\mathrm{p}}=0.4812 \mathrm{~cm}^{3} \mathrm{~g}^{-1}$ ) proved to be the most effective procedure. In this case, the specific surface area increase about 1000 times compared with that parameter for the initial material. Somehow worse results were obtained using $\mathrm{CO}_{2}$ as a modifying agent $\left(\mathrm{MG}-\mathrm{CO}_{2}\right.$, $S_{\mathrm{BET}}=538.5 \mathrm{~m}^{2} \mathrm{~g}^{-1}, V_{\mathrm{p}}=0.3047 \mathrm{~cm}^{3} \mathrm{~g}^{-1}$ ) and using microwave (MG-micr, $\quad S_{\mathrm{BET}}=429.6 \mathrm{~m}^{2} \mathrm{~g}^{-1}, \quad V_{\mathrm{p}}=$ $\left.0.2411 \mathrm{~cm}^{3} \mathrm{~g}^{-1}\right)$.

Very interesting results were obtained for the series of samples EW (Table 1). As can be seen, the specific surface area of the sample EW- $\mathrm{H}_{2} \mathrm{O}\left(S_{\mathrm{BET}}=840.6 \mathrm{~m}^{2} \mathrm{~g}^{-1}\right)$ is higher about 74 times compared to that parameter for the initial sample (WE-ini, $S_{\mathrm{BET}}=11.4 \mathrm{~m}^{2} \mathrm{~g}^{-1}$ ). Also significant development in the microporous structure is observed. The specific surface area of micropores for this biochar $\left(S_{\text {mic }}=509.3 \mathrm{~m}^{2} \mathrm{~g}^{-1}\right)$ increased 112 times compared to that parameter for the initial sample (EW-ini, $S_{\text {mic }}=4.5 \mathrm{~m}^{2} \mathrm{~g}^{-1}$ ). Also satisfactory results were obtained for the samples EW- $\mathrm{CO}_{2}$ and EW-micr, though the changes in porous structure are slightly smaller in this case compared to the sample EW- $\mathrm{H}_{2} \mathrm{O}$ (Table 1).

Analogously to the above-described samples, the series of active carbons prepared based on walnut shells (WN) is characterized by a well-developed porous structure and activation by means of water vapor in the fluidal reactor proved to be the most effective way of modification. In this case, the specific surface area also increased even about 200 times for the sample $\mathrm{WN}-\mathrm{H}_{2} \mathrm{O}\left(S_{\mathrm{BET}}=626 \mathrm{~m}^{2} \mathrm{~g}^{-1}\right)$ compared to that of the sample WN-ini $\left(S_{\mathrm{BET}}=\right.$ $3.1 \mathrm{~m}^{2} \mathrm{~g}^{-1}$ ).

Table 1 presents the cumulative area of pores $\left(S_{\mathrm{BJH}}\right)$ determined using the $\mathrm{BJH}$ method, where cylindrical pore shapes are considered $[33,34]$. To compare the values of $S_{\mathrm{BET}}$ and $S_{\mathrm{BJH}}$, it is necessary to note that $S_{\mathrm{BET}}$ is computed from the low pressure part $\left(p / p_{0} \sim 0-0.2\right)$ of the adsorption branch of the isotherm, while for estimation of $S_{\mathrm{BJH}}$, the high pressure portion of isotherm is used, primarily its desorption branch. If the pore model perfect represents pore system in the sample, these values can be close. But in the case of the presence of micropores, and when the pore shapes are different than chosen model (cylindrical) $S_{\mathrm{BET}}$ is higher than $S_{\mathrm{BJH}}$. Such situation occurs in the case of the tested carbon samples. One could expect that the sum of 
$S_{\mathrm{BJH}}$ and $S_{\text {mic }}$ will give the value of $S_{\mathrm{BET}}$. Indeed, for samples modified in fluidal reactor with steam or $\mathrm{CO}_{2}$ such tendency can be seen. The samples have a lot of micropores, and shape of the pores significantly varies from the perfect cylindrical.

\section{Thermal analysis}

Figure 2 presents the TG, DTG, and DTA curves for the all initial biochars (X-ini), and the samples obtained due to their modification in the fluidal reactor $\left(\mathrm{X}-\mathrm{CO}_{2}\right.$ and $\mathrm{X}-\mathrm{H}_{2} \mathrm{O}$ ) as well as in the microwave reactor (X-micr). On the TG curves up to $200{ }^{\circ} \mathrm{C}$, there is observed mass loss due to evaporation of physically adsorbed water and then for the initial samples (X-ini) from about $300{ }^{\circ} \mathrm{C}$ carbon matter combustion and evacuation of volatile decomposition products. It is different in the case of modified adsorbents for which combustion process starts only at higher temperature (about $380{ }^{\circ} \mathrm{C}$ ). This indicates larger thermal stability of biochars after modification.

Comparing the temperatures at which combustion process is finished one can see that for sample WS it is $900{ }^{\circ} \mathrm{C}$, for MG and EW about $1050{ }^{\circ} \mathrm{C}$ and for WN it is $1200{ }^{\circ} \mathrm{C}$. Such tendency is the result of difference in morphology of carbon matter in the studied samples and also in the size and hardness of the particles of these biochars. Biochar from wheat straw (WS) had powdery character, so heat transport to its particles was faster and its organic part could burn completely at lowest temperature in comparison with other samples.

The grains of samples MG and EW had the shape of needles and were a little harder than the WS, so these particles could be more thermal stable compared to the WS.

The most hard and compact were grains of sample WN. Heat transfer to and from the sample and penetration of air were the most difficult. On this basis, it can be assumed that this was one of the causes of the largest thermal stability of this biochar.

A comparison of the residues after combustion of organic part in the test samples shows that biochar from wheat straw (WS) had the highest content of the ash (ca $40 \%$ ) but other samples had only about $10 \%$. As we know these are commercial samples which are the residue from the processes of obtaining of gas and liquid products from plant materials. This residue can vary depending on the type and origin of the plant and also on the technology used. The analysis of the TG curves course shows that the studied carbon materials are of complex character which is reflected by the DTG and DTA curves.

From the analysis of the DTG curves in Fig. 2, one can see a few distinct peaks in different temperature ranges showing multistage character of the process in the studied biochars. However, on the DTA curves one can observe endothermic peaks corresponding to the evaporation process of physically adsorbed water $\left(\mathrm{DTA}_{\min } \sim 100^{\circ} \mathrm{C}\right)$ and then exothermic ones which come from the process of carbon matter combustion (DTA ${ }_{\max } \approx 400{ }^{\circ} \mathrm{C}$ ). Comparing position of the TG and DTA curves for the initial samples (X-ini) and after different ways of modification one can find out that treatment in the fluidal reactor in the water vapor atmosphere $\left(\mathrm{X}-\mathrm{H}_{2} \mathrm{O}\right)$ imparts larger thermal resistance for carbons. The TG curves bend at about $100{ }^{\circ} \mathrm{C}$ higher compared to those for initial materials. The same refers to the maxima of DTA peaks. At higher temperatures $900-1200{ }^{\circ} \mathrm{C}$ (depending on the sample type) distinct exothermic DTA peaks are observed. This indicates the occurrence of transitions in the inorganic residue (ash). The onset points of DTA peaks are in the following order: $\mathrm{WS}\left(870{ }^{\circ} \mathrm{C}\right)<\mathrm{EW}\left(890^{\circ} \mathrm{C}\right)<\mathrm{MG}\left(980{ }^{\circ} \mathrm{C}\right)<\mathrm{WN}$ $\left(1000{ }^{\circ} \mathrm{C}\right)$. It depends on the composition of the ash and consequently on the kind of plant. One of the most abundant mineral components in plants is silicon [13, 36, 37]. For instance, in the ashes of wheat straw, there is about $25 \%$ of $\mathrm{SiO}_{2}[36,37]$. Silicon gives the living plant good flexibility. Other main important elements are: $\mathrm{K}, \mathrm{Ca}, \mathrm{P}$, $\mathrm{Mg}, \mathrm{Na}, \mathrm{S}, \mathrm{Al}, \mathrm{Fe}, \mathrm{Mn}$, and $\mathrm{Zn}[36,38,39]$. In some cases, there is the possibility the presence of traces of some heavy metals as $\mathrm{Cu}, \mathrm{Pb}, \mathrm{Cd}, \mathrm{Hg}, \mathrm{Ni}$, or $\mathrm{Cr}$. Depending on the type of plant and the technological conditions on the stage of pyrolysis, the resulting biochar is characterized by different composition both of organic and mineral parts. This has an impact on the processes occurring during heating at high temperature. For instance, at higher content of alkali elements, such as $\mathrm{Na}$, $\mathrm{K}$ or $\mathrm{Ca}$, and $\mathrm{Mg}$, the sintering processes in the ash start at lower temperature [38]. On the basis of analysis of the DTA curves in Fig. 2, it can be concluded that the sample WS contains the highest amount of alkaline elements, and the sample WN has the least.

\section{Raman spectroscopy}

Figure 3 presents the Raman spectra of the studied biochar series and additionally for the graphitized carbon black Carbopack B. As can be seen, these spectra possess two characteristic peaks with the maxima at the wave numbers 1360 and $1590 \mathrm{~cm}^{-1}$. These bands can be assigned to the structure of diamond " $D$ " and graphite " $G$ ", respectively [40]. The band $G$ originates from the vibrations in the graphene planes of hybridization $s p^{2}$ of carbon atoms in the aromatic structures. As commonly known [41], the band $G$ becomes sharper and more intensive, e.g., for graphite [42] with the increasing degree of carbon matter graphitization, i.e., for more ordered aromatic structures. However, the band $D$, typically observed at $1350 \mathrm{~cm}^{-1}$, is 

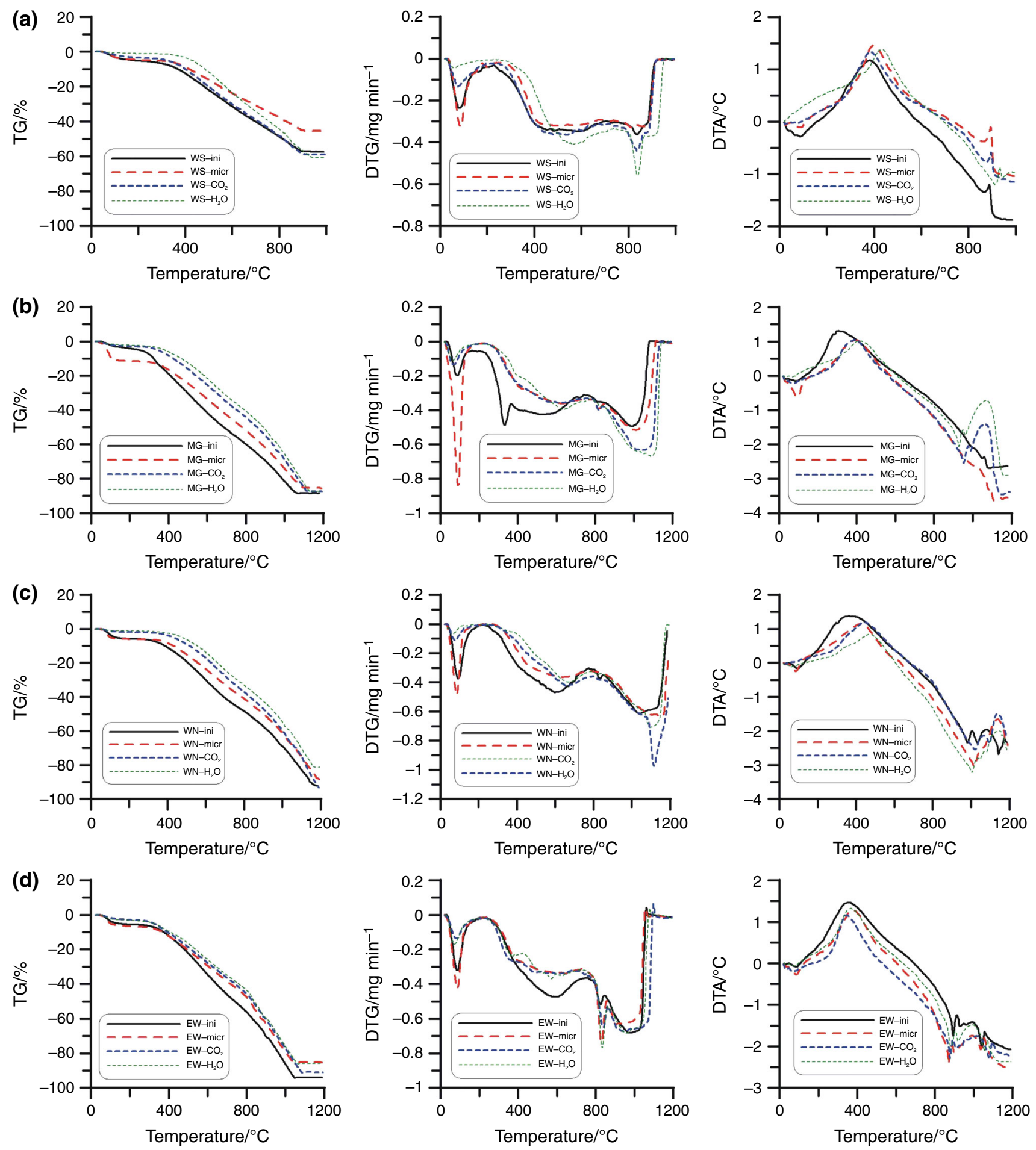

Fig. 2 TG, DTG, and DTA curves for series of biochars differently activated: wheat straw WS (a); Miscanthus grass $M G$ (b); walnut shells $W N$ (c); and energetic willow $E W(\mathbf{d})$

characteristic of disordered graphene structures of the carbon hybridization $s p^{3}$ which is characteristic of diamond structure. This disorder results from the presence of microcrystalline and turbostratic structures, significantly differing from the graphite structure.
This may also result from the presence of basal planes edges and/or heteroatoms, e.g., $\mathrm{O}, \mathrm{N}$, and $\mathrm{S}$, etc. With the increasing disorder of carbon structures both intensity and width of the band $D$ increase in relation to the band $G$. The shape of Carbopack spectrum (Fig. 3) indicates great order 

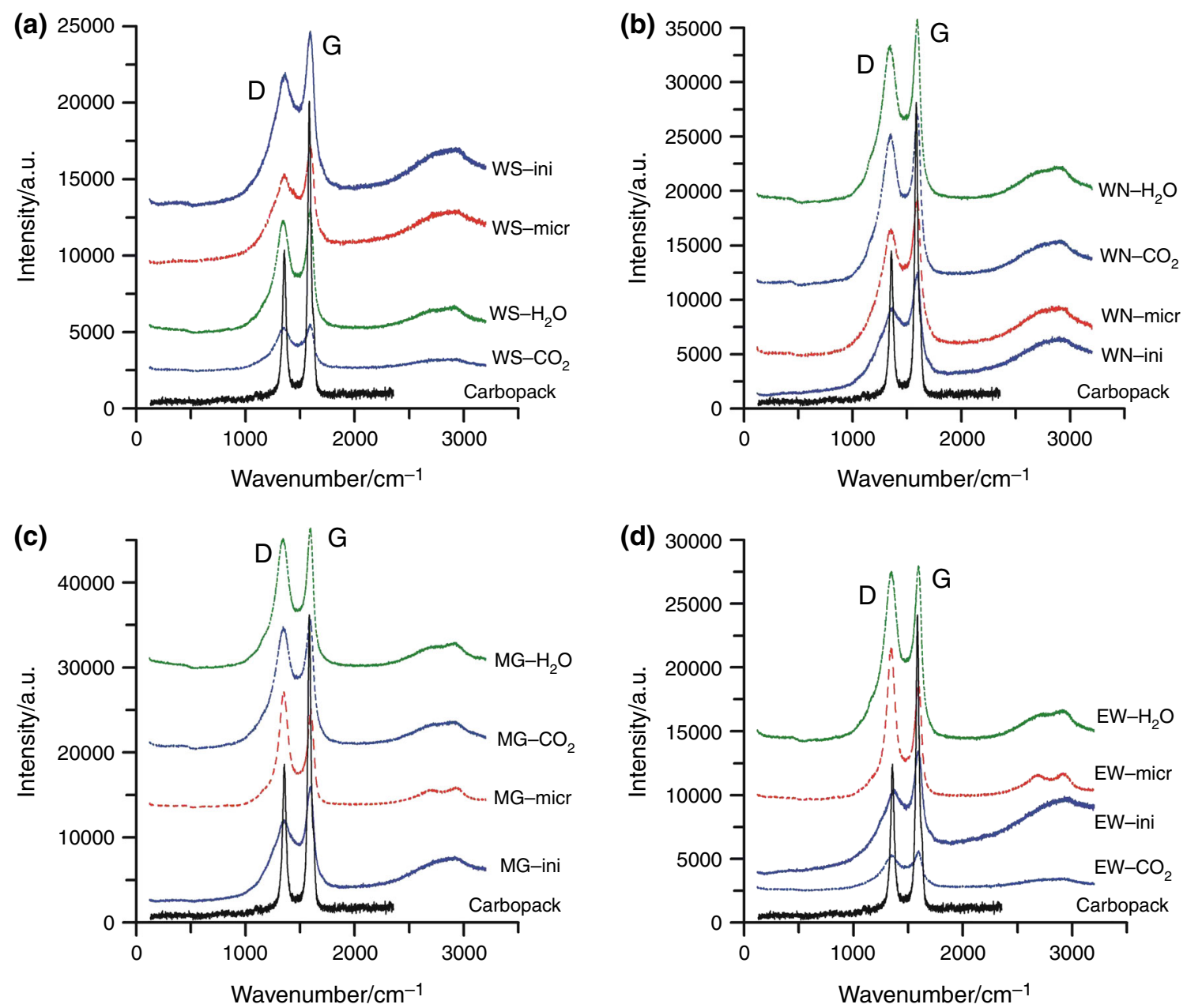

Fig. 3 Raman spectra for series of biochars differently activated: wheat straw $W S$ (a); walnut shells $W N$ (b); Miscanthus grass $M G$ (c); and energetic willow $E W(\mathbf{d})$

of carbon matter in this material due to its treatment at very high temperature (about $3500{ }^{\circ} \mathrm{C}$ ). In the case of studied biochar samples, the bands $G$ and $D$ are wider and poorly separated compared to those of Carbopack. However, their shape suggests that carbon matter has a larger content of graphite-like structures (hybridization of carbon $s p^{2}$ ), than the disordered structures characterized by a large number of carbon atoms of hybridization $s p^{3}$. As follows from the comparison of spectra in Fig. 3 for the samples after modification in both microwave and fluidal reactors, the bands $G$ and $D$ are better separated and more symmetric compared to those for the initial biochars.

\section{Microscopic studies}

Complementary data about surface morphology of the biochars are obtained from microphotographs made by the electron scanning microscopy (SEM) method. Figures 4 and 5 present the exemplary SEM photographs for the adsorbents prepared on the basis of Miscanthus grass (MG series). As can be seen, the surface quality of these samples is differentiated. In Fig. 4 (magnification $200 \times$ ), the arrangement of fibrils characteristic of plant material is presented. But there is a distinct difference in the fibrils character for the initial MG-ini sample (Fig. 4a), and the samples after various kinds of treatment (Fig. 4b, c, d). In the biochars modified in both microwave (Fig. 4b) and fluidal (Fig. 4c, d) reactors, the fibrils seen to be more distinct, uncovered, deprived of the part of carbon matter which was removed during activation and as a result of porous structure development (Table 1).

The confirmation of the discussed changes is images presented in Fig. 5 recorded at higher magnifications $(100,000 \times$ and $5000 \times)$. In Fig. 5a (magnification $100,000 \times)$, we see a smooth surface of MG-ini sample with visible pore of dimension ca. $500 \mathrm{~nm}$ and numerous bulges of about $50 \mathrm{~nm}$ in size. Modification in the microwave reactor (sample MG-micr, Fig. 5b, magnification $5000 \times$ ), substantially caused the enlargement of previously observed protuberances (bulges) to the size of about 

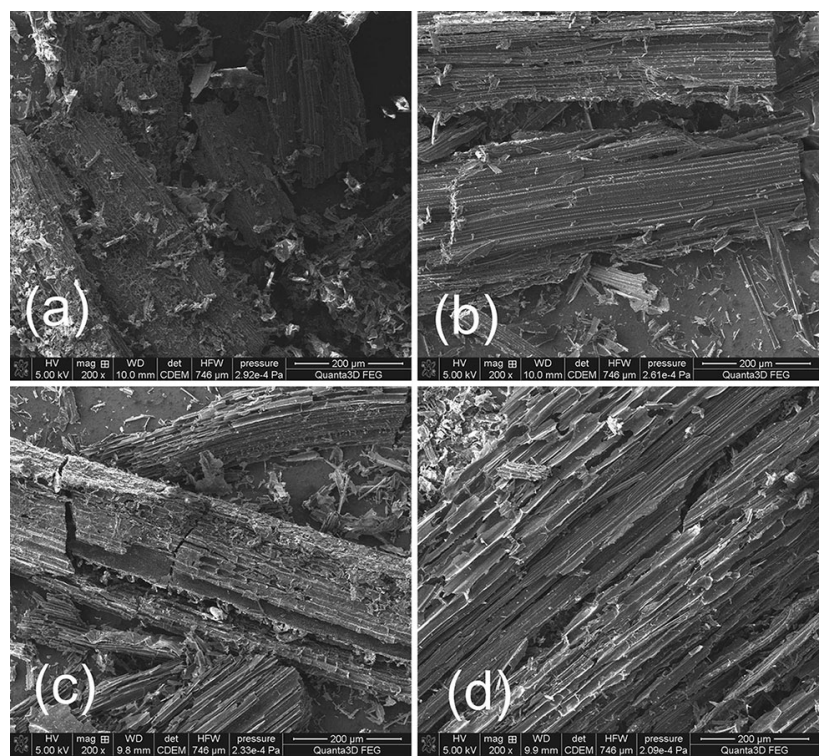

Fig. 4 SEM microphotographs for biochars based of Miscanthus grass $M G$ series differently treated: MG-ini (a); MG-micr (b); MG$\mathrm{CO}_{2}(\mathbf{c}) ; \mathrm{MG}-\mathrm{H}_{2} \mathrm{O}(\mathbf{d})$. All magnification $200 \mathrm{x}$
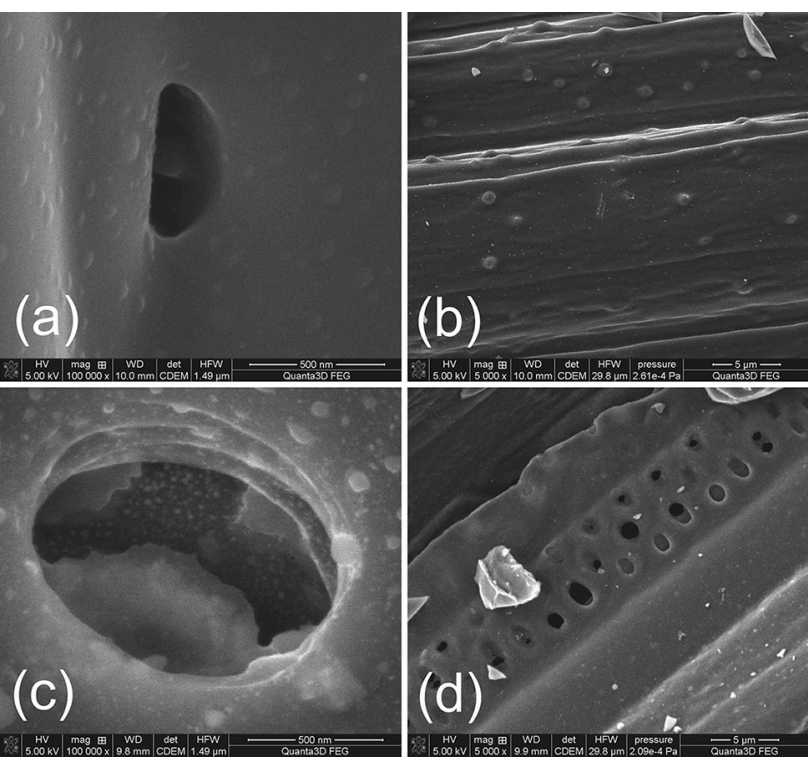

Fig. 5 SEM microphotographs for biochars based of Miscanthus grass $M G$ series differently treated: MG-ini (a); MG-micr (b); $\mathrm{MG}-$ $\mathrm{CO}_{2}$ (c); $\mathrm{MG}-\mathrm{H}_{2} \mathrm{O}$ (d). a and c magnification $100000 \times$; b and d magnification $5000 \mathrm{x}$

$600 \mathrm{~nm}$. In contrast, the activation in a fluid bed reactor with $\mathrm{CO}_{2}\left(\mathrm{MG}-\mathrm{CO}_{2}\right.$ Fig. 5c) and $\mathrm{H}_{2} \mathrm{O}\left(\mathrm{MG}-\mathrm{H}_{2} \mathrm{O}\right.$, Fig. 5d) caused noticeable changes in the topography of the surface of the obtained samples. This is particularly visible in Fig. 5c (MG- $\mathrm{CO}_{2}$, magnification of $\left.100,000 \times\right)$. Here, we see a wide pore with dimension of about $1000 \mathrm{~nm}$ with a very diversified interior and different types of protuberances. Equally interesting picture presents Fig. 5d (magnification of $5000 \times$ ) showing the surface of the sample modified with water vapor $\mathrm{MG}-\mathrm{H}_{2} \mathrm{O}$. Here, we see a plurality of pores having a diameter of from 500 to $2000 \mathrm{~nm}$ and complex corrugated surface.

\section{Conclusions}

The investigations showed that natural waste materials are good material for active carbon production. The initial biochars are characterized by very low-specific surface area and small sorption pores volume. Application of activation procedures using overheated water vapor or $\mathrm{CO}_{2}$ as modifying agents proved to be a very effective way of developing porous structure. Due to modification under oxidizing conditions, there was observed porous structure development as a result of oxidation of less structurized parts of carbon material and creation of new pores. The adsorbents obtained were characterized by a larger degree of ordering of carbon matter.

Acknowledgements The paper was prepared within the project BCAMED No. PSPB-135/2010, co-financed by Switzerland within the Swiss Program of Collaboration with new member states of the European Union. The research was carried out with the equipment purchased thanks to the financial support of the European Regional Development Fund in the framework of the Polish Innovation Economy Operational Programme (Contract No. POIG.02.01.00-06024/09 Centre for Functional Nanomaterials).

Open Access This article is distributed under the terms of the Creative Commons Attribution 4.0 International License (http://crea tivecommons.org/licenses/by/4.0/), which permits unrestricted use, distribution, and reproduction in any medium, provided you give appropriate credit to the original author(s) and the source, provide a link to the Creative Commons license, and indicate if changes were made.

\section{References}

1. Denyes MJ, Langlois VS, Rutter A, Zjeb BA. The use of biochar to reduce soil PCB bioavailability to Cucurbita pepo and Eisenia fetida. Sci Total Environ. 2012;43:776-82.

2. Atkinson CJ, Fitzgerald JD, Hipps NA. Potential mechanisms for achieving agricultural benefits from biochar application to temperate soils: a review. Plant Soil. 2010;337:1-18.

3. Barrow CJ. Biochar: potential for countering land degradation and for improving agriculture. Appl Geogr. 2012;34:21-8.

4. Lehmann J, Rillig MC, Thies J, Masiello CA, Hockaday WC, Crowley D. Biochar effects on soil biota: a review. Soil Biol Biochem. 2011;43:1812-36.

5. Glaser B, Lehmann J, Zech W. Ameliorating physical and chemical properties of highly weathered soils in the tropics with charcoal -a review. Biol Fertil Soils. 2002;35:219-30.

6. Ghosh U, Luthy RG, Cornelissen G, Werner D, Menzie CA. In situ sorbent amendments: a new direction in contaminated sediment management. Environ Sci Technol. 2011;45:1163-8. 
7. Oleszczuk P, Rycaj M, Lehmann J, Cornelissen G. Influence of activated carbon and biochar on phytotoxicity of air-dried sewage sludges to Lepidium sativum. Ecotox Environ Safe. 2012;80:321-6.

8. Oleszczuk P, Hale SE, Lehmann J, Cornelissen G. Activated carbon and biochar amendments decrease pore-water concentrations of polycyclic aromatic hydrocarbons (PAHs) in sewage sludge. Bioresour Technol. 2012;111:84-91.

9. Rakowska MI, Kupryianchyk D, Harmsen J, Grotenhuis T, Koelmans AA. In situ remediation of contaminated sediments using carbonaceous materials. Environ Toxicol Chem. 2012;31:693-704.

10. Kołtowski M, Hilber I, Bucheli TD, Charmas B, SkubiszewskaZięba J, Oleszczuk P. Activated biochars reduce the exposure of polycyclic aromatic hydrocarbons in industrially contaminated soils. Chem Eng J. 2017;310:33-40.

11. Kołtowski M, Charmas B, Skubiszewska-Zieba J, Oleszczuk P. Effect of biochar activation by different methods on toxicity of soil contaminated by industrial activity. Ecotox Environ Safe. 2017;136:119-25.

12. Diyuk VE, Mariychuk RT, Lisnyak VV. Barothermal preparation and characterization of micromesoporous activated carbons. Textural studies, thermal destruction and evolved gas analysis with TG-TPD-IR technique. J Therm Anal Calorim. 2016;124:1119-30.

13. Song K, Zhang H, Wu Q, Zhang Z, Zhou C, Zhang Q, Lei T. Structure and thermal properties of tar from gasification of agricultural crop residue. J Therm Anal Calorim. 2015;119: 27-35.

14. Savova D, Apak E, Ekinci E, Yardim F, Petrov N, Budinova T, Razvigorova M, Minkova V. Biomass conversion to carbon adsorbents and gas. Biomass Bioenerg. 2001;21:133-42.

15. Petrov N, Budinova T, Razvigorova M, Parra J, Galiatsatou P. Conversion of olive wastes to volatiles and carbon adsorbents. Biomass Bioenerg. 2008;32:1303-10.

16. Hayashi J, Horikawa T, Muroyama K, Gomes VG. Activated carbon from chickpea husk by chemical activation with $\mathrm{K}_{2} \mathrm{CO}_{3}$ : preparation and characterization. Micropor Mesopor Mater. 2002;55:63-8.

17. Suzuki RM, Andrade AD, Sousa JC, Rollemberg MC. Preparation and characterization of activated carbon from rice bran. Bioresour Technol. 2007;98:1985-91.

18. Cabal B, Budinova T, Ania CO, Tsyntsarski B, Parra JB, Petrova B. Adsorption of naphthalene from aqueous solution on activated carbons obtained from bean pods. J Hazard Mater. 2009;161: 1150-6.

19. Budinova T, Savova D, Tsyntsarski B, Ania CO, Cabal B, Parra JB, Petrov N. Biomass waste-derived activated carbon for the removal of arsenic and manganese ions from aqueous solutions. Appl Surf Sci. 2009;255:4650-7.

20. Ucar S, Erdem M, Tay T, Karagoz S. Preparation and characterization of activated carbon produced from pomegranate seeds by $\mathrm{ZnCl}_{2}$ activation. Appl Surf Sci. 2009;255:8890-6.

21. Shuo Z, Cheng-Yang W, Ming-Ming C, Zhi-Qiang S, Na L. Preparation of carbon spheres from potato starch and its stabilization mechanism. New Carbon Mater. 2010;25:438-43.

22. Guo Y, Yang S, Yu K, Zhao J, Wang Z, Xu H. The preparation and mechanism studies of rice husk based porous carbon. Mater Chem Phys. 2002;74:320-3.

23. Zielińska A, Oleszczuk P, Charmas B, Skubiszewska-Zięba J, Pasieczna-Patkowska S. Effect of sewage sludges properties on the biochar characteristic. J Anal Appl Pyrol. 2015;112:201-13.

24. Jankowska H, Świątkowski A, Choma J. Active carbon. New York: Ellis Horwood Ltd; 1991.
25. Fenelonov VB. Poristyj Uglerod. Novosybirsk: Instytut Kataliza; 1995 (in Russian).

26. Leboda R, Skubiszewska-Zięba J, Bogillo VI. Influence of gasification catalyzed by calcium and steam activation on the porous structure of activated carbons. Langmuir. 1997;13:1211-7.

27. Leboda R, Skubiszewska-Zięba J, Grzegorczyk W. Effect of calcium catalyst loading procedure on the porous structure of active carbon from plum stones modified in the steam gasification process. Carbon. 1998;36:417-25.

28. Skubiszewska-Zięba J, Leboda R, Charmas B, Grzegorczyk W, Szmigielski R. On the preparation of synthetic carbon adsorbents using the sulfonated ion exchange resin Duolite C-20. J Therm Anal Calorim. 2006;86:187-94.

29. Carrott PJM, Nabais JMV, Carrott MMLR, Menendez JA. Thermal treatments of activated carbon fibres using a microwave furnace. Micropor Mesopor Mat. 2001;47:243-52.

30. Miura M, Kaga H, Sakurai A, Kakuchi T, Takahashi K. Rapid pyrolysis of wood block by microwave heating. J Anal Appl Pyrol. 2004;71:187-99.

31. Nabais JMV, Carrott PJM, Carrott MMLR, Menendez JA. Preparation and modification of activated carbon fibres by microwave heating. Carbon. 2004;42:1309-14.

32. Menendez JA, Menendez EM, Iglesias MJ, Garcia A, Pis JJ. Modification of the surface chemistry of active carbons by means of microwave-induced treatments. Carbon. 1999;37:1115-21.

33. Gregg SJ, Sing KSW. Adsorption, surface and porosity. 2nd ed. London: Academic Press; 1982.

34. Barrett EP, Yoyner LG, Halenda PP. The determination of pore volume and area distributions in porous substances. I. Computations from nitrogen isotherms. J Am Chem Soc. 1951;73:373.

35. Rouquerol J, et al. IUPAC recommendation for the characterization of porous solids. Pure Appl Chem. 1994;66:1739-58.

36. Karcz H, Kantorek M, Grabowicz M, Wierzbicki K (2013) Możliwość wykorzystania słomy jako źródła paliwowego w kotłach energetycznych (The feasibility of straw as a fuel source for power generating boilers). Inżynieria Środowiska, Piece Przemysłowe \&Kotły. XI-XII: 8-15.

37. Atik Celik, Ates Saim. Mass balance of silica in straw from the perspective of silica reduction in straw pulp. BioResources. 2012;7:3274-82.

38. Coulson M, Dahl J, Gansekoele E, Bridgwater AV, Obernberger I, van de Beld L (2004) Ash characteristics of perennial energy crops and their influence on thermal processing. In: 2nd World Conference on Biomass for Energy, Industry and Climate Protection, 10-14 May 2004, Rome, Italy.

39. Piekarczyk M, Kotwica K, Jaskulski D. The elemental composition of ash from straw and hay in the content of their agricultural utilization. Acta Sci Pol Agricultura. 2011;10:97-104.

40. Kruk M, Kohlhaas KM, Dufour B, Celer EB, Jaroniec M, Matyjaszewski K, Ruoff RS, Kowalewski T. Partially graphitic, high-surface-area mesoporous carbons from polyacrylonitrile templated by ordered and disordered mesoporous silicas. Micropor Mesopor Mat. 2007;102:178-87.

41. Koizumi N, Urabe $\mathrm{Y}$, Inamura K, Itoh T, Yamada M. Investigation of carbonaceous compounds deposited on NiMo catalyst used for ultra-deep hydrodesulfurization of gas oil by means of temperature-programmed oxidation and Raman spectroscopy. Catal Today. 2005;106:211-8.

42. Sadezky A, Muckenhuber H, Grothe H, Niessner R, Poschl U. Raman microspectroscopy of soot and related carbonaceous materials: Spectral analysis and structural information. Carbon. 2005;43:1731-42. 